\title{
Evaluation of the Effect of Independent Audit Quality and Ownership Structure on Earnings Management in the Listed Companies of Tehran Stock Exchange
}

\author{
AlirezaTaheriLisar ${ }^{* 1,2}$, PeimanImanZadeh ${ }^{3}$ \\ ${ }^{I}$ Department of Accounting, Ardabil Science and Research branch, Islamic Azad University, Ardabil, \\ Iran \\ ${ }^{2}$ Department of Accounting, Ardabil Branch, Islamic Azad University, Ardabil, Iran \\ ${ }^{3}$ Department of Accounting, Talesh Branch, Islamic Azad University, Talesh, Iran
}

\begin{abstract}
The main objective of this study is to evaluate the effect of independent audit quality and ownership structure on earnings management. In this study, independent audit quality and ownership structureas the dependent variable and earnings management as the independent variable were tested. The research method, in terms of purpose, is functional and in term of method, is descriptive and correlational and also in terms of time, it is a kind of causative research. Data collection method is library and sampling method in recent study is screening that 170 companies had been investigated during the period. Spatial domain of the research is listed companies on Tehran Stock Exchange and its time domain is the 5-years period from2010 to 2014. Also, in order to analyze and test research hypotheses, multivariate regression method was used. The results of the study indicate that the audit qualityhas no effect on management. And shows that ownership structure effects on earnings management. The results also show that the ownership structure does not modify the relationship between audit quality and earnings management.
\end{abstract}

Keywords: independent audit quality, ownership structure, earnings management, debt ratio, firm size

\section{Introduction}

Earning is one of the major items of the financial statements that attract the attention of users of financial statements to it. Investors, creditors, analysts, governments and other users of financial statements, use earning as a basis for investment decisions making, lending,performance evaluation, etc.(Mahdavi and et al. 2013). But net profit is not a profit unit affected by accounting methods and estimates. Managers' authority in applying the principles of research, matching and estimating and forecast and also apply methods such as changing the way of valuation of inventory, amortization of goodwill, processing costs or investing,treatment of the research and development cost and determined doubtful debt expense are items that managers can change profits by applying them. On the one hand, because of greater awareness company directors, it is expected to prepare and present information in a way that reflects the company's status in the best way. On the other hand, because of reasons such as retention of the company, receive reward and etc. manager of the non-profit unit may be show off the company situation desirable by manipulating intentionally or unintentionally.

Under such circumstances, the real profit conflict with reported profit in the financial statements and an even occurs as the earnings management (Mojtahedzadeh et al., 2012).

As an observer mechanism, the essential role of the audit is something like ownership structure; reduce inconsistent information between managers andshareholders (Jones, 2011 and Usman 2012). With regard to the privatization process has been accelerated by the implementation of Article 44 of constitutional law, need for high quality auditingoffinancial statements for the admission of their shares in Tehran Stock Exchange is necessary. There are in spite of managers 'incentives to applied management in earnings, it is necessary to investigate and determine the effect of audit quality and ownership structure on earnings management in order to provide information to make better decisions of users in this statements.

With regard to the separation of ownership from management, the company's strategic system discussion and its related theories such as representation theory, stakeholder theory and other related theories, the need to review and audit of financial statements is felt. Audited financial statements haveaddedvalue.Because results reported the capability of reliance on the content of financial statements (HasasYeganeh, 2005). Audit can be one of the preventive and reduction methods of earnings management, because reported earnings, in the audited financial statements, haveInformationalcontain and high quality (Hanif, 2010). Earning managing is one of the confounding factors of the quality of financial reporting and all the company's stakeholders paying attention tothem. Because any kind of intervention that divers the accuracy of reported earnings, effected on the users decision-making (Zangin and Ozkan, 2010).According to the above discussion, 
the question arises is "what is the effect ofthe independent audit quality and ownership structure on the earnings management of the Firms listed in the Tehran Stock Exchange?

\section{Research hypothesis}

1- Independent audit quality effects on the earnings management.

2- Ownership structure effects on the earnings management.

3- The relationship between the independent audit quality and earnings management are moderated by the presence of ownership structure.

\section{Research variables \\ Independent variable}

Quality of independent auditing: in order to determine audit quality, variable of audit size was use as virtual variable. In the event that the auditor of the client's company was the audit organization during the study period, the value of virtual variable size equals to one and otherwise it equals to zerowere considered. Auditor's independent membership in auditing organization is an indicator for measuring the quality of auditing that is a dummy variable.

If he/sheis a member of the audit organization, equals to zero andotherwise equals to one.

Institutional ownership: to calculate the total institutional ownership of the collected stocks in the authority of banks and insurance,holdings, investmentcompanies, pension funds, finance companies and investment funds, organizations and government agencies and state-owned enterprises divided in to the total stocks and the percentage or institutional ownership value has been obtained.

Earnings management:Based on conducted studies by Dechaw and et al (1995), Jones's modified model is the strongest model for measuring of earnings management. Accordingly, in this study, the above model has been used to calculate discretionary accruals. In Jones's modified model, total of accruals are calculated as follows:

$\mathrm{TA}_{\mathrm{it}}=\mathrm{E}_{\mathrm{it}}-\mathrm{OCF}_{\mathrm{it}}$

$\mathrm{TA}_{\mathrm{it}}$ : total accrual of $i$ company in year $t$

$\mathrm{E}_{\mathrm{it}}$ : profit before extraordinary accrual for $i$ company in year $t$

$\mathrm{OCF}_{\mathrm{it}}$ : Obtained Cash flow from operations for $i$ company in year $t$

After calculating total accrual, parameters $a_{1}, a_{2}, a_{3}$ in order to determine involuntary accruals, estimates through following formula:

$$
\frac{T A_{i t}}{A_{i n-1}}=\alpha_{1} \frac{1}{A_{i n-1}}+\alpha_{2} \frac{\Delta R E V}{A_{i n-1}}+\alpha_{3} \frac{P P E_{t}}{A_{i n-1}}+\varepsilon
$$

Where in:

$\mathrm{TA}_{\mathrm{it}}$ : total accruals in icompany in year $t$

$\mathrm{A}_{\mathrm{i}, \mathrm{t}-1}$ :total value of $i$ company assets at the end of year $t-1$

$\triangle \mathrm{REV}_{\mathrm{it}}$ : change in sales revenue between year $\mathrm{t}$ and $\mathrm{t}-1$

$\mathrm{PPE}_{\mathrm{it}}$ : gross property, machinery and equipment of $i$ company in year $t$

$\varepsilon_{\mathrm{it}}$ : uncertain effects of random factors

$a_{1}, a_{2}, a_{3}$ :estimatedparameters by $i$ company

After calculating $a_{1}, a_{2}, a_{3}$ parameters through the method of least squares according to the following formula of non-discretionary accruals, will be determinedas follow:

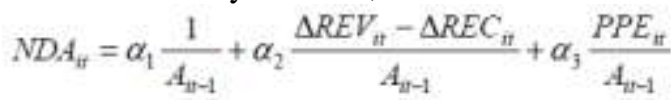

Where in:

$\mathrm{NDA}_{\mathrm{it}}$ : discretionaryaccrualsof $i$ company in year $t$ :

$\triangle \mathrm{REC}$ it: change in receivable accounts of $i$ company between year $t$ and $t-1$ :

Eventually discretionary accruals (DA) was calculated after determining NDA as follow

$$
D A=\frac{T A}{A_{i t-1}}-N D A
$$

Firm size: is acriteriathat has been used to determine big or small firms. In order to its measurement, criteria such as the value of assets, sales, stock market value and number of shares can be used. In thisresearch,in order to measure firm size, the natural logarithm of total assert was used.

Debt ratio: it is a ratio that indicate what proportion of total debt is related to its assets.

Debt ratio is calculated by dividing total debt to total assets. As follows: 
Debt ratio $=\frac{\text { debt }}{\text { total asset }}$

\section{Research model}

The hypothesis is tested by using the following models:

To test hypothesis 1:

$\mid$ DAit $\mid=\alpha 0+\alpha 1$ BIGit $+\alpha 2$ SIZEit $+\alpha 3$ LEVit $+\varepsilon i t$

To test hypothesis 2 :

$\mid$ ADit $\mid=\alpha 0+\alpha 1$ IPit $+\alpha 2 S I Z$ Eit $+\alpha 3$ LEVit + eit

To test hypothesis 3 :

$\mid$ ADit $\mid=\alpha 0+\alpha 1$ BIGit $+\alpha 2$ IPit $+\alpha 3$ SIZEit $+\alpha 4 L E V i t+\varepsilon i t$

Data analysis

Table 1

\begin{tabular}{|l|l|l|l|}
\hline & Model 1 & \\
\hline & Value of coefficient & T statistics & Significant level \\
\hline BIG & $9.48 \mathrm{E}+10$ & 0.481509 & 0.6303 \\
\hline SIZE & $1.40 \mathrm{E}+12$ & 4.799400 & 0.0000 \\
\hline LEV & $9.27 \mathrm{E}+10$ & 1.461864 & 0.1441 \\
\hline fix value & $-1.64 \mathrm{E}+13$ & -4.699179 & 0.0000 \\
\hline Value of F statistic & 65.85 & \multicolumn{3}{l}{} \\
\hline Significant level & 0.0000 & \multicolumn{2}{l}{} \\
\hline Determination coefficient & 0.18 & \multicolumn{4}{l}{} \\
\hline Durbin Watson & 1.96 &
\end{tabular}

According to the significant level of review model is more than 0.05, then examined hypothesis is rejected.As a result, there is no significant relationship between independent audit quality and earnings management.

Table2

\begin{tabular}{|l|l|l|l|}
\hline & Model 1 & Significant level \\
\hline & Value of coefficient & T statistics & 0.009 \\
\hline IP & $-4.75 \mathrm{E}+11$ & -2.600791 & 0.0000 \\
\hline SIZE & $1.49 \mathrm{E}+12$ & 4.557469 & 0.1189 \\
\hline LEV & $9.14 \mathrm{E}+10$ & 1.560983 & 0.0000 \\
\hline fix value & $-1.71 \mathrm{E}+13$ & -4.510651 & \\
\hline Value of F statistic & 68.74 & \multicolumn{3}{|l}{} \\
\hline Significant level & 0.0000 & \\
\hline Determination coefficient & 0.19 & \multicolumn{3}{|l}{} \\
\hline Durbin Watson & 1.96 &
\end{tabular}

According to the significant level of review model is more than 0.05 , then examined hypothesis was approved by 0.95 confident coefficients.

Table 3

\begin{tabular}{|l|l|l|l|}
\hline & Model 1 & Significant level \\
\hline & Value of coefficient & T statistics & 0.4747 \\
\hline BIG & $1.48 \mathrm{E}+11$ & 0.715187 & 0.0152 \\
\hline IP & $-5.18 \mathrm{E}+11$ & -2.432358 & 0.0000 \\
\hline SIZE & $1.46 \mathrm{E}+12$ & 4.671292 & 0.1166 \\
\hline LEV & $9.15 \mathrm{E}+10$ & 1.570727 & 0.000 \\
\hline fix value & $-1.68 \mathrm{E}+13$ & -4.632562 & \\
\hline Value of F statistic & 51.63 & \\
\hline Significant level & 0.0000 & \\
\hline Determination coefficient & 0.19 & \\
\hline Durbin Watson & 1.95 & \\
\hline
\end{tabular}

According to that the coefficient of determination has not changed, as a result third hypothesis is rejected, then the relationship between the independent audit quality and earning management did not adjusted in spite of ownership structure.

\section{Conclusion}

The first hypothesis of the present study, examines the impact of the independent audit quality on earnings management. The findings show that the audit quality does not effect on earnings management in the overall state. This result indicates to the positive impact of the audit organization existence, as the audit firm, with a good reputation and credibility, on the level of earnings management and the weakness of this result 
impact on the different structures of the earnings management of firms.Generally, the results of the research contrary to the findings of Becker and et al (1998) and Frances and et al (1999) and complies with Namazi and et al'sresearch (2012).Second hypothesis of the study, examines the impact of ownership structure on earning management. Generally, the research evidence suggests that the concentration of ownership structure has an impact on earnings management, so institutional investors implies active monitoring role on corporate decisions about their earnings management.Research evidence suggests that with increasing the percentage of institutional ownership of stock, flexibility of the company in order to manage earningswasreduced.The third hypothesis of this study investigated the relationship between the independent audit quality and earnings management despite the ownership structure. The obtained results of the research showed that ownership structure does not modify the relationship between audit quality and earnings management.

\section{References}

[1]. HasasyeganehYahya (2005), "audit philosophy ", Tehran, Scientific and Cultural Publishing Company, First Edition.

[2]. Mojtahedzadeh. Vida, Babaee. Zahra (2012) "The impact of independent audit quality on earnings management and stock capital costs", Empirical Research in Financial Accounting, Issue 4, Pages 13.

[3]. Mahdavi.GholamHossein,Hosseini.SeyedMojtaba, Raiesi. Zohre, (2013)"The impact of corporate governance characteristics on predicted earnings quality by the management of listed companies in Tehran Stock Exchange ", Journal of Management Accounting Research, Sixth year, Issue XV, Spring2013

[4]. Dechow, p.m and Sloan, R, and Sweeny, A, (1995), "Detecting Earnings Management", The Accounting Review, Volum 70, Issue 2, pp: $193-225$

[5]. Hashi, Iraj, (2003), "The Legal Framework for Effective Corporate Governance: Comparative Analysis of Provisions on Selected Transition Economies", Stanfordshire University Business School Press.

[6]. Jones, J.(2011). Creative accounting fraud and international accounting scandals(Edition: November). Wiley.

[7]. Usman, S,H, Yero, J, I. (2012). Ownership concentration and earning management practice of Nigerian listed conglomerates. American International Journal of Contemporary Research, 2(7), 157-171

[8]. Zengn, K, Y. \&Ozkan, S. (2010). "Audit Quality and Earning Management in Interim Financial Reports",Electronic Copy Available At: http://ssrn.com/abstract=1733070. 